\title{
Incumbent party support and perceptions of corruption - an experimental study
}

\author{
Zoltán Kmetty \\ https://doi.org/10.51624/SzocSzemle.2018.4.7 \\ Manuscript received: 19 June 2018. \\ Modified manuscript received: 10 December 2018. \\ Acceptance of manuscript for publication: 20 December 2018.
}

\begin{abstract}
In the recent national election in April 2018 in Hungary, the incumbent party (Fidesz) won again. During the campaign period, some of the media were full of stories about the scandals and corruption affairs of Fidesz. However, election results showed that these scandals did not decrease incumbent party support. What is the potential explanation for this? During the election campaign, we conducted an online survey experiment in Hungary, giving different treatments to respondents within the different sub-samples. The former were asked to read an article about a relevant corruption affair connected to different political actors. Our main hypothesis was that if people hear about scandals related to the government, support for the incumbent party will decrease. Results of the fitted logistic regression models suggest that information about incumbent-related corruption scandals did not affect voting for the incumbents. The most interesting result was that dominantly pro-government media consumers were more likely to vote for Fidesz after treatment compared to the control group. We thus think that the selection of information, the perceived credibility of sources, and information processing were influenced by partisanship. In a natural reaction, partisan respondents recalled their party identity and tried to respond to questions from the related viewpoints.
\end{abstract}

Keywords: corruption, information hypothesis, trade-off hypothesis, incumbent support, experimental research

\section{Introduction}

The negative effects of political corruption are widely known. Overall, it decreases economic performance and weakens trust and confidence in institutions and the government (Mishler - Rose 2001, Anderson - Tverdova 2003). Widespread malfeasance can create significant disillusionment with the whole political system (Seligson 2006, Olson 2014). One the one hand, if people do not believe they can change a corrupt situation, electoral participation may decrease (Manzetti and Wilson 2007), while on the other hand, corruption may also lead to mobilization against the incumbent party (Kostadinova 2009).

Eastern Europe is a good area to examine how corruption affects political participation and the electoral arena. Between 2000 and 2010 corruption and scandals were a major issue in 70 percent of the elections in this region that were analyzed and the typical Eastern European voter perceives that their politicians are more likely to 
be corrupt than in the rest of Europe (Klasjna et al. 2016). Based on Transparency International's Corruption Index, Hungary is one of the most tainted countries in this region as far as corruption is concerned (Jávor - Jancsis 2016). Hungary was thirtyninth on the list in 2007, and had slipped to sixty-sixth by 2017. ${ }^{1}$ National elections were held in Hungary on April 8, 2018. Fidesz, the right-conservative party, has been in power since 2010 in Hungary and in the last few years the media has reported on several corruption scandals involving the ruling party. Even the son-in-law of the Prime Minister was accused of corruption in a European Anti-Fraud Office (OLAF) report related to suspicious procurement activities. ${ }^{2}$ The opposition parties have tried to build their election campaign around this government malfeasance, and in social media these accusations have generated a lot of discussion (Index 2018). After a very intensive campaign, the turnout rate in 2018 reached 70 percent (the second highest since the regime change in 1990). However, this high participation level was not the result of a mobilized opposition but rather to the unexpectedly strong turnout of incumbent supporters. Fidesz received nearly half of all votes, and benefited from an increase in the number of voters by 5 percent, or 400,000 people. Why is it that the corruption accusations did not harm the incumbent party? One possible explanation is that due to the highly centralized pro-government media system in Hungary (Bajomi 2013), some voters live in such a closed media bubble that they did not hear about these scandals in the news. Another explanation is that incumbent voters evaluate corruption as irrelevant because of their own personal gains or an overall positive evaluation of economic conditions.

Based on an online survey experiment conducted before the election, we tested whether information about the government and the scandals involving Fidesz politicians might decrease support for the incumbent party. In this paper, we present the result of this survey experiment and offer a possible explanation for the unexpectedly high level of support for the incumbent party.

\section{Theoretical Background}

Corruption can be hard to quantify, and it is also hard to identify its exact boundaries. From a theoretical viewpoint, we can distinguish between experiential corruption and perceived corruption. The prior is usually connected with minor or petty issues, while the latter is the consequence of grand corruption scandals (Ruhl 2011). There is some evidence that experiential corruption might have a greater effect on political behaviour than perceived corruption (Klasjna et al. 2016) but the latest results in Hungary have proved that perceived corruption plays a substantial role in voting

1 https://www.transparency.org/research/cpi/overview

2 For more details see, for example: https://www.theguardian.com/world/2018/feb/12/how-hungarian-pms-supporters-profitfrom-eu-backed-projects 
behaviour (Kostadinova - Kmetty 2018). Thus, in this paper, we focus on perceived corruption.

The relationship between perceived corruption and political participation is highly controversial. Perceptions of corruption may boost participation aimed at removing incumbent parties from power, but a high level of perceived corruption might also make the incumbent party's supporters unsure about the value of their votes. Widespread perceptions of malfeasance can also decrease trust in the whole political system and can cause massive withdrawal from voting. Overall, these complex mechanisms might balance each other out (Kostadinova 2009).

But how do supporters of an incumbent party deal with the corruption affairs of a government in power? There are two alternative hypotheses (Winters and WeitzShapiro 2013): one is the information hypothesis, while the other is the trade-off hypothesis. As opposed to experienced corruption, political corruption is not part of everyday life. If voters are not aware of politicians' malfeasance, they might easily support the party again in the following election. Media investigation of political corruption requires plenty of resources, and a lack of the former might leave corrupt activities hidden. In addition, the source of the accusations counts. If incumbent supporters do not trust sources, they might also mistrust their information. However, if they receive credible information about corrupt activities, they might withdraw their support. This so-called information hypothesis has not been clearly supported by experimental studies that focused on this issue, but more papers have backed the hypothesis (Ferraz - Finan 2008, Chong et al 2011, Figueiredo et al 2011, Winters Weitz-Shapiro 2013) than have rejected it (Banerjee et al. 2010).

The other possible explanation focuses on the overall advantage of supporting the incumbent party. Even if the pro-governing party voters are aware of the malfeasance of the politician they support they might evaluate this as irrelevant when they cast their ballots. Many reasons can be listed here to support this behaviour. If overall economic conditions are good in the country and it is on a solid path of development, the governing party can withstand even the biggest corruption scandal. This is also true if incumbent party voters feel that the other parties are also corrupt, and thus perceive that corruption is the nature of politics and it is inevitable that there are corruption scandals in a long-term government cycle. It is also possible that voters will not punish their party if they also obtain private goods from the current system (Manzetti - Wilson 2007). Several studies have supported this trade-off hypothesis (Rundquist et al. 1977, Manzetti - Wilson 2006, Banerjee - Pande 2009), but there are contradictory findings too (Winters - Weitz-Shapiro 2013).

When analyzing the effect of corruption scandals, it is also crucial to understand and consider how people get their information about politics and public life. The Hungarian political media is polarized and strongly allied along partisan lines (Szabó and Kiss 2011). The Fidesz government controls a strongly centralized media system which continuously echoes their messages (Bajomi 2013). The country is highly 
polarized (Körösényi 2013), the distance between government and anti-government supporters is very wide, and political homophily (Kmetty - Koltai 2012) is very strong. All these factors increase the chance of that "opinion bubbles" will form. Recently, many scholars have talked about such opinion bubbles (Iyengar et al. 2012), which refer to the fact that people watch/read/listen to only those channels that are in line with their own political views and where they find only similar opinions to their own. This homogenous opinion milieu significantly decreases the quality of political orientation and increases the distance between political sides. Such a fragmented political field can strongly hinder political information flow (Pariser 2011). Such a political and media space might prevent voters from getting information about scandals released to the other side of the political field.

In this paper, we test how polarized media consumption affect incumbent party support when voters are confronted with information about real scandals.

\section{Hypotheses}

Following the unexpected election results in Hungary, we tested whether the information hypothesis is relevant in Hungary regarding corruption issues and incumbent support. We hypothesized (H1) that if people hear about scandals related to the government (negative framing of Fidesz), support for the incumbent party will decrease. This is a classic test of the information hypothesis (Ferraz - Finan 2008, Chong et al. 2011, Figueiredo et al. 2011, Winters - Weitz-Shapiro).

Since the media is very polarized in Hungary, and Fidesz has taken over a lot of media sources in recent years, we might assume that some voters have not heard reports about government-related malfeasance. Based on this, we hypotheses that support for the incumbents of those who consume dominantly pro-government media will be weaker (H2).

The first two expectations were built on the information hypothesis. However, we wanted to test whether the trade-off hypothesis holds as well. In H3 we hypotheses that Fidesz corruption treatment would not affect those who were satisfied with their own living conditions (H3a), and/or those who perceived a high level of exposure to the corruption of the opposition parties (H3b).

\section{Design of the experimental surveys}

During the election campaign, we conducted an online survey experiment (Mutz 2011a). The survey was administered ${ }^{3}$ between December 12, 2017, and January 10, 2018, four months before the general election of April 8, 2018. The sample size was 
1000 respondents; the survey was representative for Hungarian internet users aged 18 or older.

The survey was broken down into four sub-samples (see Table 1) each of whose respondents we gave different treatments to. The former were asked to read an article about a relevant corruption affair connected to one of three political actors. We chose scandals which had been heavily cited by news channels within the last one year. The present Hungarian political arena is dominated by three political entities (Kovarek and Soós 2017): Besides the incumbent party (Fidesz), there is a (formerly) extremeright party (Jobbik), ${ }^{4}$ and a fragmented left political coalition with three bigger parties: the Hungarian Socialist Party (MSZP), Demokratikus Koalíció (DK), and Lehet Más a Politika (LMP). We chose one scandal connected to Fidesz, one scandal connected to Jobbik, and one connected to MSZP. The fourth sub-sample was the control group which did not receive any treatment. The stories involved real scandals, and the articles were based on published news (we simply shortened the texts). ${ }^{5}$

Table 1. Structure of the questionnaire design

\begin{tabular}{|c|c|c|c|}
$\begin{array}{c}\text { Fidesz corruption } \\
\text { treatment }(\mathrm{N}=255)\end{array}$ & $\begin{array}{c}\text { Jobbik corruption } \\
\text { treatment }(\mathrm{N}=253)\end{array}$ & $\begin{array}{c}\text { Socialist party (MSZP) } \\
\text { corruption treatment } \\
(\mathrm{N}=247)\end{array}$ & Control group (N=245) \\
\hline \multicolumn{2}{c}{ Questions about corruption } \\
\hline \multicolumn{2}{c}{ Questions about party support and political participation }
\end{tabular}

After the corruption treatment, respondents were asked to evaluate the level of corruption in Hungary, the dynamics of the spread of corruption, and the exposure to corruption of each party. After this block of questions, respondents provided information in response to standard political survey questions such as voting intention, party support, party sympathy, etc.

\section{Analytical strategy and variables}

In the analysis, we fitted multivariate statistic models using the dependent variable incumbent (Fidesz) support. We measured Fidesz election support with a dummy variable based on the "Which party would you vote for?" question. We coded "1" those who said they would vote for Fidesz, and the others "0". As the dependent variable has two categories, binomial logistic regression models were used in the analysis. ${ }^{6}$ To present the results, we calculated the average marginal effect $\left(\mathrm{AME}^{7}\right)$ of

\footnotetext{
4 Jobbik has started to move to the centre from the right over the last few years.

5 For the corruption treatment condition, see the questionnaire.

6 To test the robustness of our models we calculated all of the models with a linear predictor too. Results were the same as in the case of logistic regression models.

7 We used the statistical programme R's margins package (Leeper 2018) to calculate the AME.
} 
the explanatory variables. The AME helps to overcome the problem of interpreting interaction terms in logistic regressions. To test our hypothesis, we fitted several models with different independent variables.

In Model 1 (M1 - for testing H1) the incumbent corruption treatment (ICT) variable was used as an independent variable besides the control variables. The ICT variable was coded with two categories: "0" - control group or other party corruption; "1" - corruption treatment related to Fidesz corruption.

To test the effect of selective media consumption (M2), we added a composite media orientation variable to the first model with two categories: "0" - dominantly not pro-government media consumption, "1" - dominantly pro-government media consumption. ${ }^{8}$ To test $\mathrm{H} 2$, the interaction term of the ICT variable and the media orientation variable was added to the model.

To test the trade-off hypothesis (M3), we added two additional variables to the M1 model: opposition parties' corruption exposure (an 11-category scale ranging from "not corrupt at all" (0) to "very corrupt" (10)) and the financial situation of the respondent's household (5-category scale ranging from "we live in financial deprivation" (1) to "we live without financial worries" (5)). The interaction term of these two latter variables with the treatment variable was added to the model to test $\mathrm{H} 3$.

To control the basic demographic variables, gender, age-cohort (three categories) settlement type, and education (four categories) variables were included into the model. One-quarter of the sample read about a government corruption case, while one-quarter of them did not read anything (the control group). The other half of the sample was asked to read a news article about scandals involving other parties. To control for this effect, two additional dummy variables were included in the models: Jobbik corruption treatment and Socialist party corruption treatment. The descriptive statistics for the variables are available in Appendix Table A1.

\section{Results}

The first regression model (Table1, M1) contains the three treatment variables as dummies (the control treatment group was the reference here), the pro-government media consumption variable, and the demographic variables.

8 In the first step, we created four variables:

Watch pro-government television channel news (M1, DunaTV, TV2)

Watch anti-government television channel news (RTL, HírTV, ATV)

Read pro-government newspapers and news sites (Origo, Lokál, Magyar Hírlap, Magyar Idők)

Read anti-government newspapers and news sites (Index, 24.hu, HVG, 444, Alfahír, Kuruncinfo, Magyar Nemzet, Népszava,

Vasárnapi Hírek)

We coded as "dominantly pro-government media consumers" those who:

Either watch or read pro-government media sources and do not watch/read any anti-government media sources.

Watch and read pro-government media sources but do not watch and read anti-government media sources together.

To categorize the sources, we used a classification by Mérték Média Műhely: www.mertek.eu. 
The model was significant (Chi-square sig=0.000), but overall explanatory power was quite low (Cox-Snell R Square: 0.074): only the settlement and media consumption variables had significant effects. Fidesz had higher support in the county seats and the other cities compared to the capital city of Budapest. The media consumption variable played the strongest role in the model (based on Wald statistics): those who dominantly watch and/or read pro-government media sources support the incumbent party 30 percentage points more based on the marginal effects. The incumbent corruption treatment variable was not significant, and thus the information hypothesis did not stand in terms of the whole sample. This represents a rejection of $\mathrm{H} 1$.

Table 2. Binomial logistic regression models. Dependent variable: incumbent voting

\begin{tabular}{|c|c|c|c|c|c|c|c|c|c|}
\hline & \multicolumn{3}{|c|}{ M1 } & \multicolumn{3}{|c|}{ M2 } & \multicolumn{3}{|c|}{ M3 } \\
\hline & B & Sig. & AME & B & Sig. & AME & B & Sig. & AME \\
\hline Constant & $-2,543$ & 0,000 & & $-2,453$ & 0,000 & & $-5,615$ & 0,000 & \\
\hline Gender & $-0,152$ & 0,391 & -0.020 & $-0,157$ & 0,376 & $-0,021$ & 0,096 & 0,615 & 0,013 \\
\hline Age: $18-34$ & $-0,119$ & 0,594 & -0.015 & $-0,138$ & 0,539 & $-0,017$ & $-0,397$ & 0,102 & $-0,051$ \\
\hline Age : $35-49$ & 0,12 & 0,563 & 0.016 & 0,094 & 0,651 & 0,013 & $-0,074$ & 0,738 & $-0,010$ \\
\hline $\begin{array}{c}\text { EDU4 - ISCED } \\
\text { categorization }\end{array}$ & 0,195 & 0,116 & 0.026 & 0,199 & 0,11 & 0,026 & $-0,05$ & 0,713 & $-0,007$ \\
\hline $\begin{array}{c}\text { Settlement: county } \\
\text { seat }\end{array}$ & 0,556 & 0,047 & 0.067 & 0,532 & 0,057 & 0,064 & 0,538 & 0,07 & 0,062 \\
\hline $\begin{array}{c}\text { Settlement: other } \\
\text { city }\end{array}$ & 0,589 & 0,026 & 0.072 & 0,567 & 0,033 & 0,069 & 0,668 & 0,018 & 0,081 \\
\hline Settlement: village & 0,503 & 0,082 & 0.06 & 0,496 & 0,085 & 0,059 & 0,806 & 0,009 & 0,101 \\
\hline Treatment: Fidesz & $-0,362$ & 0,145 & -0.048 & $-0,657$ & 0,026 & $-0,051$ & $-5,932$ & 0,005 & $-0,087$ \\
\hline Treatment: Jobbik & $-0,343$ & 0,166 & -0.045 & $-0,349$ & 0,154 & $-0,046$ & $-0,341$ & 0,189 & $-0,046$ \\
\hline Treatment: Socialist & 0,062 & 0,792 & 0.008 & 0,05 & 0,83 & 0,007 & $-0,044$ & 0,862 & $-0,006$ \\
\hline $\begin{array}{c}\text { Dominantly pro- } \\
\text { government media }\end{array}$ & 1,602 & 0,000 & 0.291 & 1,379 & 0,000 & 0,295 & & & \\
\hline $\begin{array}{l}\text { Treatment: Fidesz } \\
\text { * Dominantly pro- } \\
\text { government media }\end{array}$ & & & & 0,993 & & & & & \\
\hline $\begin{array}{l}\text { Opponent party's } \\
\text { corruption exposure }\end{array}$ & & & & & & & 0,277 & 0,000 & 0,05 \\
\hline $\begin{array}{l}\text { Treatment: Fidesz } \\
\text { * Opponent party's } \\
\text { corruption exposure }\end{array}$ & & & & & & & 0,461 & & \\
\hline $\begin{array}{l}\text { Financial situation } \\
\text { of the household }\end{array}$ & & & & & & & 0,384 & 0,002 & 0,06 \\
\hline $\begin{array}{l}\text { Treatment: Fidesz * } \\
\text { Financial situation } \\
\text { of the household }\end{array}$ & & & & & & & 0,304 & & \\
\hline Model test (Chi2) & & 0,000 & & & 0,000 & & & 0,000 & \\
\hline Cox and Snell R2 & & 0,074 & & & 0,078 & & & 0,098 & \\
\hline
\end{tabular}

To test if Fidesz corruption treatment played a special role within different segments of media consumption groups, we added the interaction term of pro-government media consumption and ICT. In this model (Table 2 - M2) the significance level of the ICT variable declined to under 0.05 in a negative direction, meaning the treatment decreased incumbent support. In the case of the non-linear models, the standard calculation of the significance level of the interaction term is biased (Ai-Norton 
2003) so we omitted it from the tables. It is not easy to understand and interpret an interaction term, so we plotted the AME of the Fidesz treatment variable in different media environments (see Figure 1). Those respondents who did not read/watch progovernment media have a negative average marginal effect, but those who live in incumbent media bubble have a positive effect.

Figure 1.: Average marginal effect of Fidesz treatment in the case of different types of media consumption

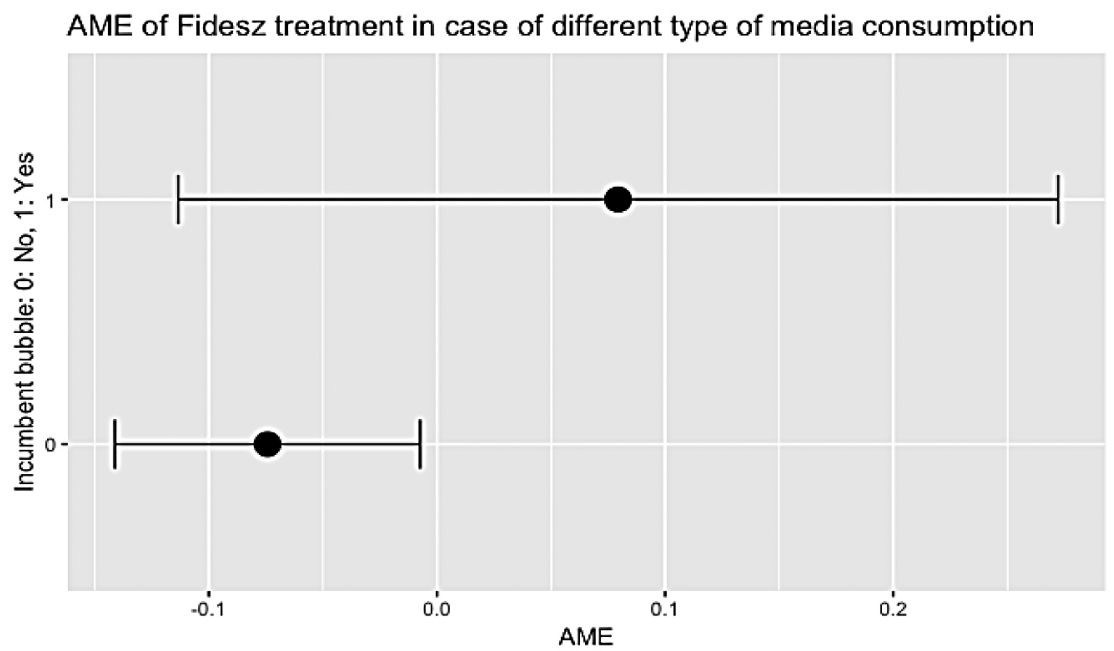

We expected that the corruption treatment would decrease Fidesz support within the population who watch and/or read mostly pro-government media, but the findings contradicted our expectations. Fidesz support was even higher in the former group. This suggests rejecting the information hypothesis, and raises the question why we got the entirely opposite result to the one we expected. We come back to this point in the discussion.

Our last hypothesis involves the trade-off hypothesis. We expected that individuals who live in good economic conditions (H3a) and/or those who feel that the opposition parties are (also) corrupt (H3b) would resist the ICT. We tested these hypotheses (H3a, H3b) in Model 3 (Table 2 - M3). This model had the greatest explanatory power (Cox-Snell R square=0.098). To test H3 we needed to focus on the interaction terms.

The Fidesz treatment group's AME value for different levels of economic situation was quite uniform with very limited variation, so we rejected H3a. The interaction of Fidesz treatment and the opposition party corruption variable was more interesting. Figure 2 helps us understand the mechanism here. The ICT did not affect those who assumed that opposition parties are corrupt, but for those who did not associate 
opposition parties with strong corruption, ICT decreased level of support for Fidesz. This result reinforces Hypothesis $3 b$ about the trade-off effect.

Figure 2.: Average marginal effect of Fidesz treatment on perceptions of different levels of opposition party corruption

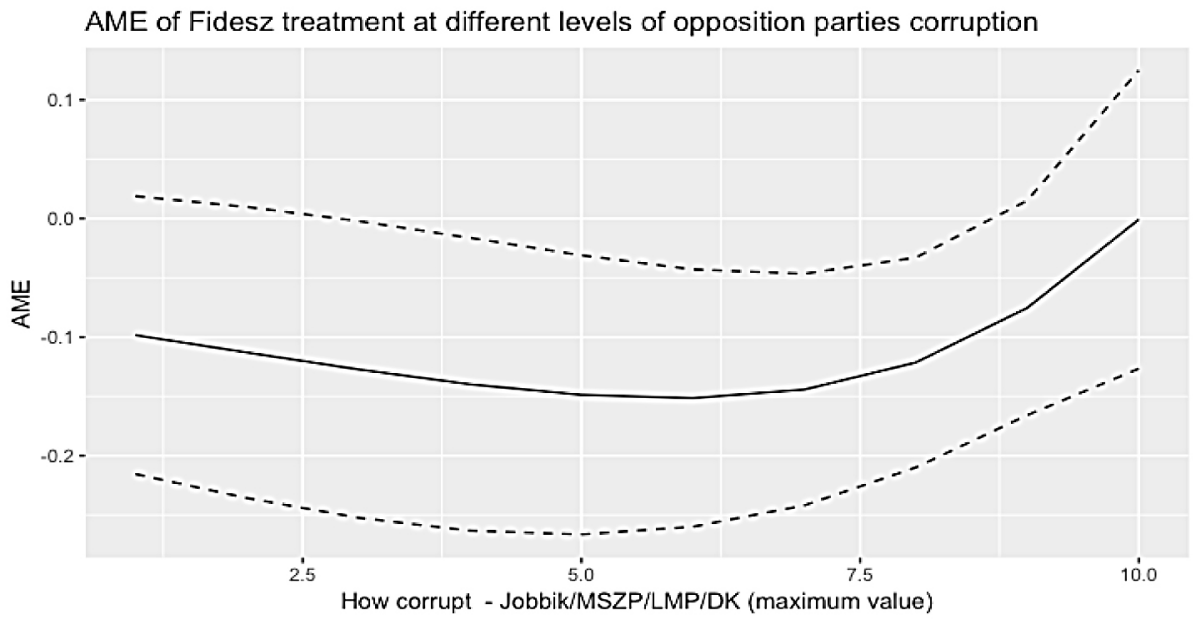

\section{Discussion}

Fidesz won the recent election of April 2018 in Hungary, and was able to increase their proportion of supporters and absolute numbers of voters compared to four years ago. During the campaign period, some parts of the media weres full of stories about the scandals and corruption affairs of Fidesz which generated an extremely high level of interaction in social media (Index 2018).

An OLAF report was released about the possible corruption exposure of Prime Minister Viktor Orbán's son-in-law (István Tiborcz). Another emblematic government figure, Zsolt Semjén, was accused of accepting a high-value invitation to a hunt financed by an entrepreneur. Photos of their hunt in Sweden (the shot reindeer was transported by helicopter ${ }^{9}$ dominated the media for several days. However, election results showed that these scandals did not decrease incumbent party support. What possible explanation is there for this? There is evidence from other experiments (Klasjna Tucker 2013) that in countries where the perception of corruption is very high, new scandals or accusations do not change anything. As people already have negative opinions about the whole system, and all the parties, they use different criteria when they choose between parties. This claim is somewhat similar to that of the trade-off

9 For the whole story, see: https://budapestbeacon.com/semjen-might-have-illegally-downed-a-reindeer-in-sweden/ 
hypothesis which was partly accepted in this paper (H3b). Our results showed clearly that those who felt that other parties are also corrupt supported Fidesz at the same level in the treatment and the control group. In opposition to the trade-off hypothesis, we therefore reject the information hypothesis. The ICT did not affect voting for the incumbent (H1).

The most interesting result came from the analysis of the media consumption effect. We hypothesized that the support of those who watch/read dominantly progovernment media sources for the political incumbents would weaken after the ICT. The results showed just the opposite tendency: dominantly pro-government media consumers were more inclined to vote for Fidesz in the ICT groups than in the control group. What might have happened here?

There is a growing body of literature that deals with the mechanisms behind partisan identity (Janky 2018). Partisanship may influence the selection of information, the perceived credibility of sources, and information processing (Mutz 2011b). If a voter receives information which is not in line with their partisan identity, they might refuse to pay attention to it and start collecting counter-arguments (Bolsen et al. 2014). As a natural reaction, the partisan respondent recalls their party identity and tries to answer any question from this perspective. The literature calls this "motivated reasoning" (Leeper - Slothuus 2014). Bechtel et al. (2015) found in an experimental study conducted in Switzerland that media-framing associated with immigrants alienates different political sides as it leads to recall of the partisanship identity of respondents. We might assume the same process in the case of ICT. Those who dominantly watch/read pro-government media sources receive a comprehensive narrative about events in Hungary. This is a relatively small group (15 percent of the sample), but the proportion of Fidesz voters is above 40 percent within this group (but only 13 percent of the rest of the sample). When these individuals read a framing that is different to the one they are used to hearing, their political identity starts to work, and they start to defend their political side. This is a very important finding because it might help with understanding why previous experiments and research have produced mixed results.

There is other possible explanation for the weak mobilizing effect of ICT. Overall perceptions of corruption are very high in Hungary, with all parties considered to be corrupt by 70 percent of all voters (Kmetty 2018). When corruption is so widespread, voters might feel hopeless about changing the situation. As fighting corruption requires collective action, people have to believe that others will also fight against corruption. Without this, corruption cannot be a defining phenomenon behind political behaviour.

It seems that, despite growing access to online space, media consumption is heavily defined by partisanship. Real news and fake news are not always easy to differentiate. Politicians have started questioning the truth promoted by media outlets. Trump 
does this in the USA, and Viktor Orbán does the same in Hungary. This may have serious consequences for media consumption and media evaluation. From a research perspective, this is an important challenge. When testing the type of treatments that we did in this study, we should monitor not just the media consumption of respondents but also the evaluation of different media sources from the perspective of trustworthiness.

In our experiment we used real scandals and conducted our survey during a campaign period. In a politically more stressful period such as this, recall of partisanship identity may be much stronger than in a calmer period. Further research is needed to understand this mechanism better.

\section{Appendix}

Table A1.: Descriptive table of main variables

\begin{tabular}{|c|c|c|}
\hline Variable & Response categories & Frequency (\%) \\
\hline \multirow{2}{*}{ Party support } & Other party, does not vote & 82,3 \\
\hline & Incumbent party & 17,7 \\
\hline \multirow{2}{*}{ Media orientation variable } & $\begin{array}{c}\text { Dominantly non pro-government media } \\
\text { consumption }\end{array}$ & 84,6 \\
\hline & $\begin{array}{l}\text { Dominantly pro-government media } \\
\text { consumption }\end{array}$ & 15,4 \\
\hline \multirow{2}{*}{ Gender } & male & 47 \\
\hline & female & 53 \\
\hline \multirow{3}{*}{ Age (3-cat) } & 18-34 years & 25 \\
\hline & $35-49$ years & 28 \\
\hline & $50+$ years & 47 \\
\hline \multirow{4}{*}{ Settlement } & Budapest & 21,2 \\
\hline & county seat & 23,7 \\
\hline & other town & 32,1 \\
\hline & village & 23 \\
\hline \multirow{5}{*}{ Financial situation } & we live in financial deprivation & 4,9 \\
\hline & we have financial problems every month & 14,6 \\
\hline & we make ends meet & 42,8 \\
\hline & get along well financially & 32,9 \\
\hline & we live without financial worries & 4,8 \\
\hline
\end{tabular}




\section{References}

Ai C. - Norton E. C. (2003): Interaction terms in logit and probit models. Economics letters, 80(1), 123-129.

Anderson C. J. - Tverdova Y. (2003): Corruption, Political Allegiances, and Attitudes Toward Government in Contemporary Democracies. American Journal of Political Science 47(1): 91-109. https://doi.org/10.1111/1540-5907.00007

Bajomi-Lázár P. (2013): The Party Colonization of the Media: The Case of HungaryEast European Politics and Societies and Cultures 27(1): 69-89.

Banerjee A.V. - Pande R. (2007): Parochial politics: Ethnic preferences and politician corruption. Working paper. Available at: http://epod.cid.harvard.edu/files/epod/ files/parochial_politics.pdf (last accessed: 2018-04-19)

Banerjee A.V. - Green D.- Green J. and Pande R. (2010): Can voters be primed to choose better legislators? Experimental evidence from rural India. Working paper. Available at: http://citeseerx.ist.psu.edu/viewdoc/download?doi=10.1.1.371.762 6\&rep=rep1\&type=pdf (last accessed: 2018-04-19)

Bauhr M. (2017): Need or greed? Conditions for collective action against corruption. Governance, 30(4), 561-581.

Bechtel MM, Hainmueller J, Hangartner D and Helbling M (2015) Reality bites: The limits of framing effects for salient and contested policy issues. Political Science Research and Methods 3(3): 683-695. https://doi.org/10.1017/psrm.2014.39

Bolsen T. - Druckman J. N. - Cook F.L. (2014): The influence of partisan motivated reasoning on public opinion. Political Behavior 36(2): 235-262. https://doi. org/10.1007/s11109-013-9238-0

Chong A. De La O - Karlan D. - Wantchekon L. (2011): Looking Beyond the Incumbent: The Effects of Exposing Corruption on Electoral Outcomes. National Bureau of Economic Research. Working Paper (No. w17679)

Ferraz C. - Finan F. (2008): Exposing corrupt politicians: the effects of Brazil's publicly released audits on electoral outcomes. The Quarterly Journal of Economics, 123(2): 703-745. https://doi.org/10.1162/qjec.2008.123.2.703

de Figueiredo M.F.P. - Hidalgo D. -Kasahara Y. (2010): When do voters punish corrupt politicians? Experimental evidence from Brazil. Working paper. Available: http:// conferences.wcfia.harvard.edu/sites/projects.iq.harvard.edu/files/gov2126/files/ mdefigueiro_hidalgo_voters.pdf (last accessed: 2018-04-19)

Index (2018): A Facebook alapján az ellenzék jött jól ki a kampányból (Based on Facebook, opposition parties were more successful in the campaign). News article https://index.hu/belfold/2018/valasztas/2018/04/07/a_facebook_alapjan_az_ ellenzek_jott_ki_jol_a_kampanybol/ (last accessed: 2018-04-19)

Iyengar S. - Sood G. - Lelkes Y. (2012) Affect, Not IdeologyA Social Identity Perspective on Polarization. Public Opinion Quarterly 76(3): 405-431. https://doi. org/10.1093/poq/nfs038 
Janky B. (2018): Politikai identitás és társadalmi attitűdök - a szociológiai/társadalmi szemléletmód visszatérése a politikatudományba (Political Identity and social attitudes - the comeback of sociological viewpoint to the political science). In. Tóth PP (ed.): Siófokról indultam. Farkas János emlékkötet, Gondolat, Bp. Hungary Jávor I. - Jancsics D. (2016): The role of power in organizational corruption: an empirical study. Administration \& Society 48(5): 527-558. https://doi. org/10.1177/0095399713514845

Klasnja M. - Tucker J. A. (2013): The Economy, Corruption, and the Vote: Evidence from Experiments in Sweden and Moldova. Electoral Studies 32(3): 536-543. https://doi.org/10.1016/j.electstud.2013.05.007

Klasnja M. - Tucker J. A. - Deegan-Krause K. (2016): Pocketbook vs. sociotropic corruption voting. British Journal of Political Science 46(1): 67-94. https://doi. org/10.1017/S0007123414000088

Kmetty Z. - Koltai J. (2012): The embeddedness of political participation into political discourse. Conference paper presented at: EUSOC 11th International Doctoral Seminar in Social Sciences. Available at: https://www.researchgate.net/ publication/267438281_The_embeddedness_of_political_participation_into_ political_discourse (last accessed: 2018-04-19)

KmettyZ. (2018): Korrupció percepciója, pártosság, választási részvétel: Hogyan változott a szavazók véleménye a hazai politikai korrupcióról a 2014-2018-as parlamenti ciklus alatt? In: Böcskei, Balázs; Szabó, Andrea (szerk.) Várakozások és valóságok. Parlamenti választás 2018. Budapest: Napvilág Kiadó, MTA TK PTI, p. 292

Körösényi A. (2013): Political polarization and its consequences on democratic accountability. Corvinus Journal of Sociology and Social Policy 4(2): 3-30.

Kostadinova T. (2009): Abstain or Rebel: Corruption Perceptions and Voting in East European Elections. Politics and Policy 37(4): 691-714. https://doi.org/10.1111/ j.1747-1346.2009.00194.x

Kostadinova T. - Kmetty Z. (2018): Corruption and Political Participation in Hungary: Testing Models of Civic Engagement. Working paper

Kovarek D. - Soós G. (2017): Cut from the Same Cloth? A Comparative Analysis of Party Organizations in Hungary. In: Sobolewska-Myślik K, Kosowska-Gąstoł B and Borowiec P (eds) Organizational Structures of Political Parties in Central and Eastern European Countries. Jagiellonian University Press, pp.185-208

Leeper T. J. (2018): Margins: Marginal Effects for Model Objects. R package version 0.3 .23 .

Leeper T.J. - Slothuus R. (2014): Political parties, motivated reasoning, and public opinion formation. Political Psychology 35(S1): 129-156. https://doi.org/10.1111/ pops. 12164

Manzetti L. - Wilson C. J. (2006): Corruption, Economic Satisfaction, and Confidence in Government Evidence from Argentina. The Latin Americanist 49(2): 131-139. https://doi.org/10.1111/j.1557-203X.2006.tb00078.x 
Manzetti L. - Wilson C. J. (2007): Why Do Corrupt Governments Maintain Public Support? Comparative Political Studies 40(8): 949-70. https://doi. org/10.1177/0010414005285759

Mishler W and Rose R (2001) What Are the Origins of Political Trust? Testing Institutional and Cultural in Post-Communist Societies. Comparative Political Studies 34(1): 30-62. https://doi.org/10.1177/0010414001034001002

Mutz D. C. (2011a): Population-based survey experiments. Princeton University Press. https://doi.org/10.1515/9781400840489

Mutz D. C. (2011b): Political psychology and choice. In. Goodin R (ed) Oxford Handbook of Political Science, 345-364. https://doi.org/10.1093/ oxfordhb/9780199604456.013.0018

Olsson S. A. (2014): Corruption and Political Participation. QoG Working Paper Series 2014(12) 12

Pariser E. (2011): The filter bubble. London. Penguin Press.

Persson A. - Rothstein B. - Teorell J. (2013): Why anticorruption reforms failsystemic corruption as a collective action problem. Governance, 26(3), 449-471.

Ruhl J. M. (2011): Political Corruption in Central America: Assessment and Explanation. Latin American Politics and Society 53(1): 33-58. https://doi. org/10.1111/j.1548-2456.2011.00108.x

Rundquist B.S. - Strom G.S. - Peters JG (1977): Corrupt Politicians and Their Electoral Support: Some Experimental Observations. American Political Science Review 71(3): 954-63. https://doi.org/10.1017/S0003055400265179

Seligson M. A. (2006): The Measurement and Impact of Corruption Victimization: Survey Evidence from Latin America. World Development 34(2): 381-404. https:// doi.org/10.1016/j.worlddev.2005.03.012

Szabó G. and Kiss B. (2011): Trends in Political Communication in Hungary: A Postcommunist Experience Twenty Years after the Fall of Dictatorship. The International Journal of Press/Politics 17(4): 480 - 496. https://doi. org/10.1177/1940161212452448

Winters M. S. - Weitz-Shapiro R. (2013) Lacking Information or Condoning Corruption: When Do Voters Support Corrupt Politicians? Comparative Politics 45(4): 418-436. https://doi.org/10.5129/001041513X13815259182857

\section{Data file and questionnaire}

http://openarchive.tk.mta.hu/378/ - DOI:10.17203/KDK378. 